\title{
Annual Variation of Planktonic Vegetation, 1933.
}

\author{
By \\ H. W. Harvey, M.A., \\ Hydrographer at the Plymouth Laboratory.
}

With 5 Figures in the Text.

Since February, 1933, quantitative hauls have been made at frequent intervals with the measuring net previously described in this Journal, Vol. XIX, pp. 761-773, at the entrance to Plymouth Sound and seaward thereof. The more usual positions are shown in the sketch chart, Figure 1. On passing out of Plymouth Sound the salinity of the water increases more or less rapidly, according to the state of the tide and flow from the rivers, until near the position $\mathrm{L}_{3}$, after which the increase is gradual. In winter or after heavy weather the water becomes noticeably more transparent in the neighbourhood of $\mathrm{L}_{3}$.

Although the water at $\mathrm{L}_{4}$, three miles beyond $\mathrm{L}_{3}$, is not beyond the immediate influence of the land, it would seem that more or less open sea conditions are reached there. Observations made up to 15 miles farther seaward in March, April, and May showed that the phytoplankton did not remain the same either in composition or abundance, but suggested that observations at $\mathrm{L}_{4}$ gave a measure of conditions farther to seaward. For this reason, and because it is accessible by motor boat during fine weather, most of the observations of this preliminary first year's survey were made at $\mathrm{L}_{4}$ and the inshore positions.

In most cases the net was lowered twice to 20 metres depth or once to 40 metres, during which operation it filtered between 200 and 350 litres of water, according to the drift of the ship and the length of time the net had been in use. A small portion of the catch was usually reserved to examine the nature of the plankton, and to note the dominant species of plants. The remainder was used to estimate " units of plant pigment" per cubic metre of water filtered (p. 771). The vertical sections, Figures 2, 3 , and 4 , show the changing density of population on passing away from the shore and the rapid changes which take place in quite short intervals of time, which are also shown in Figure 5. The values shown in Figures 2, 3,4 are in many cases the average of a number of observations.

Many of the lesser changes which take place are doubtless due to the mass of water which occupied the area having moved away to be replaced 
by other water, bringing its own flora with it. The incoming water is usually of similar salinity and has previously occupied similar areas. Any big change in the flora brought in with a new water mass would indicate that the new water came from an area having different conditions for plant growth, and it is therefore probable that such a change would be

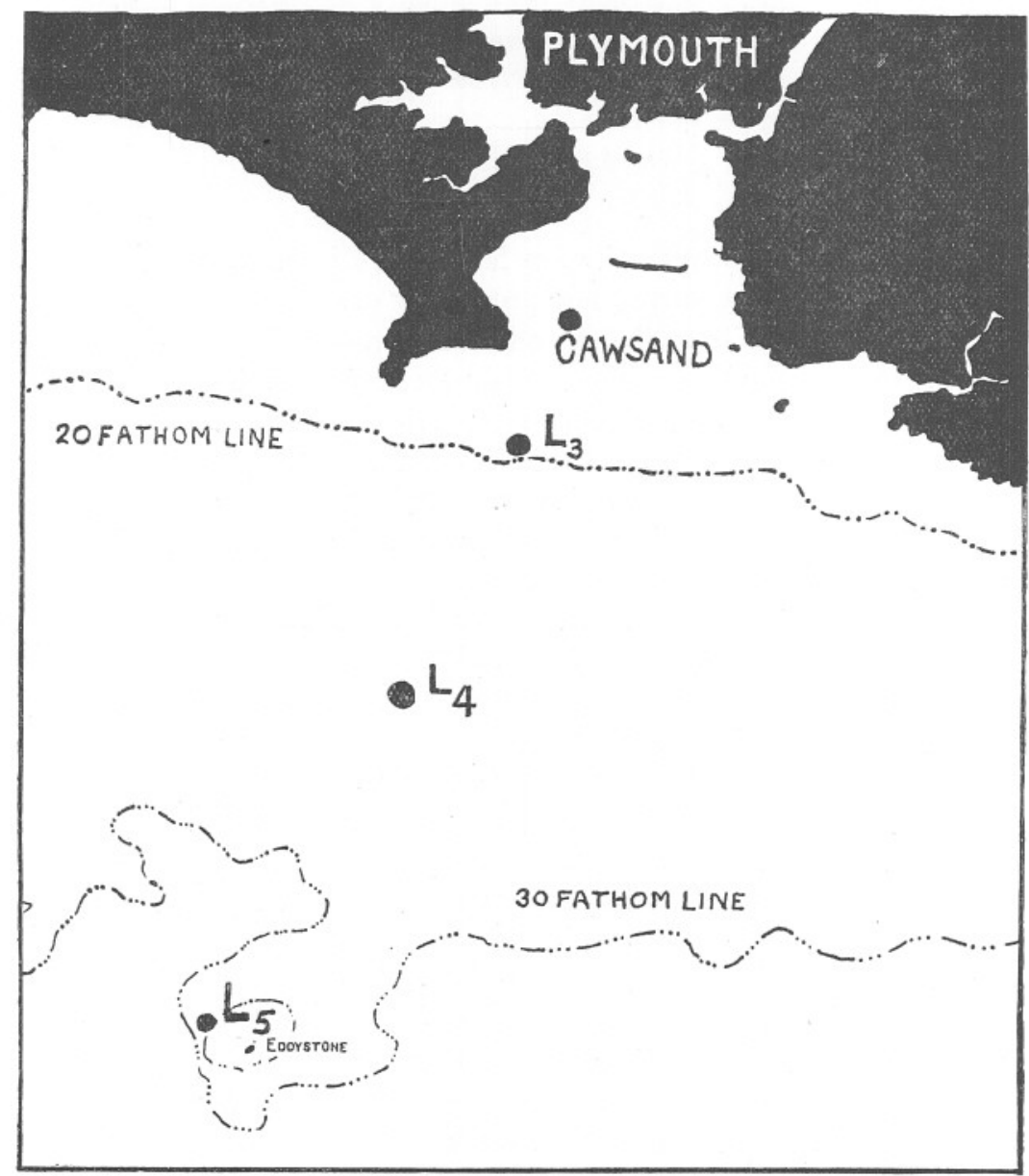

FIG. 1.

accompanied by a considerable change in salinity. Provided no marked salinity changes take place it seems justifiable to consider the area as a closed one for the purpose of describing the seasonal changes in plant life within it, although we know that water may be frequently replaced by water of similar history, but the possibility has to be borne in mind that a 

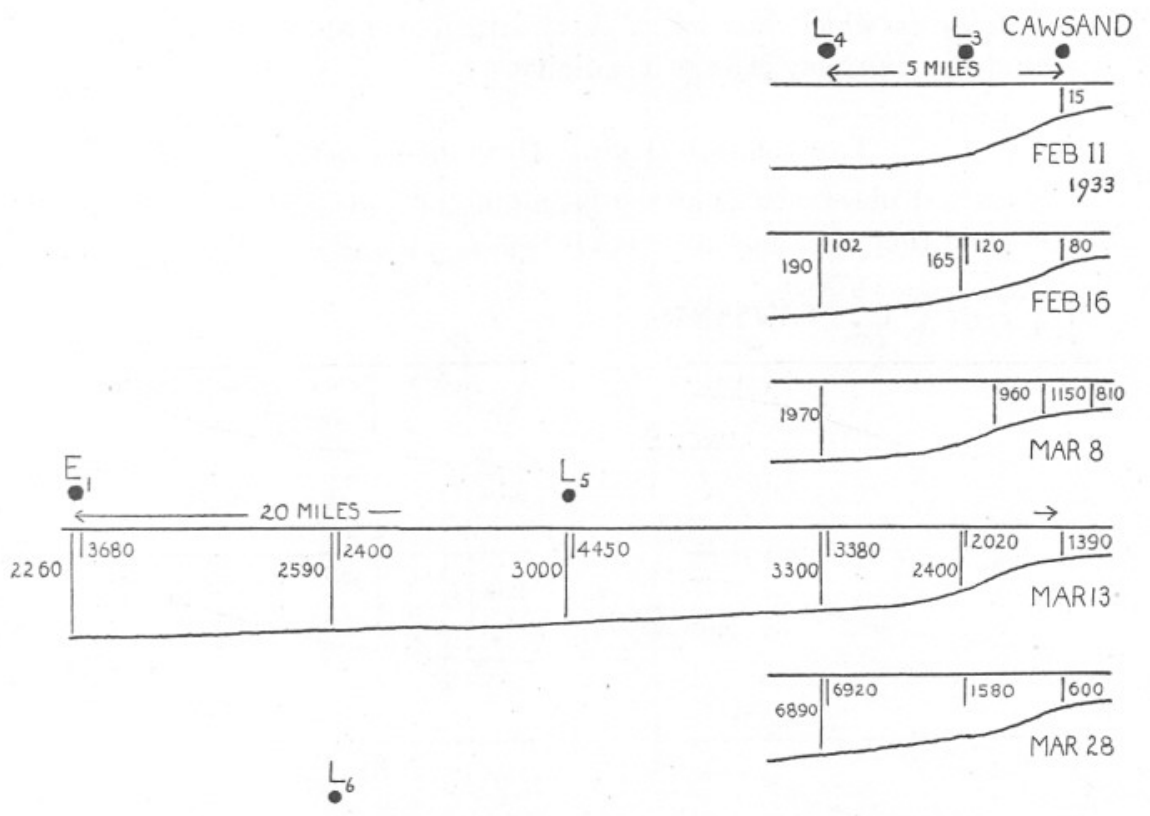

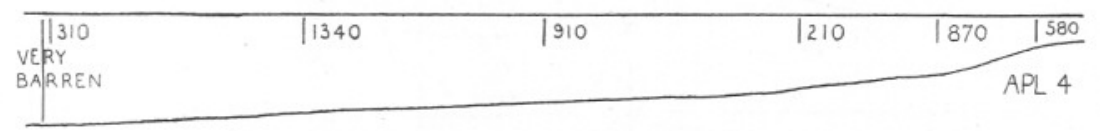
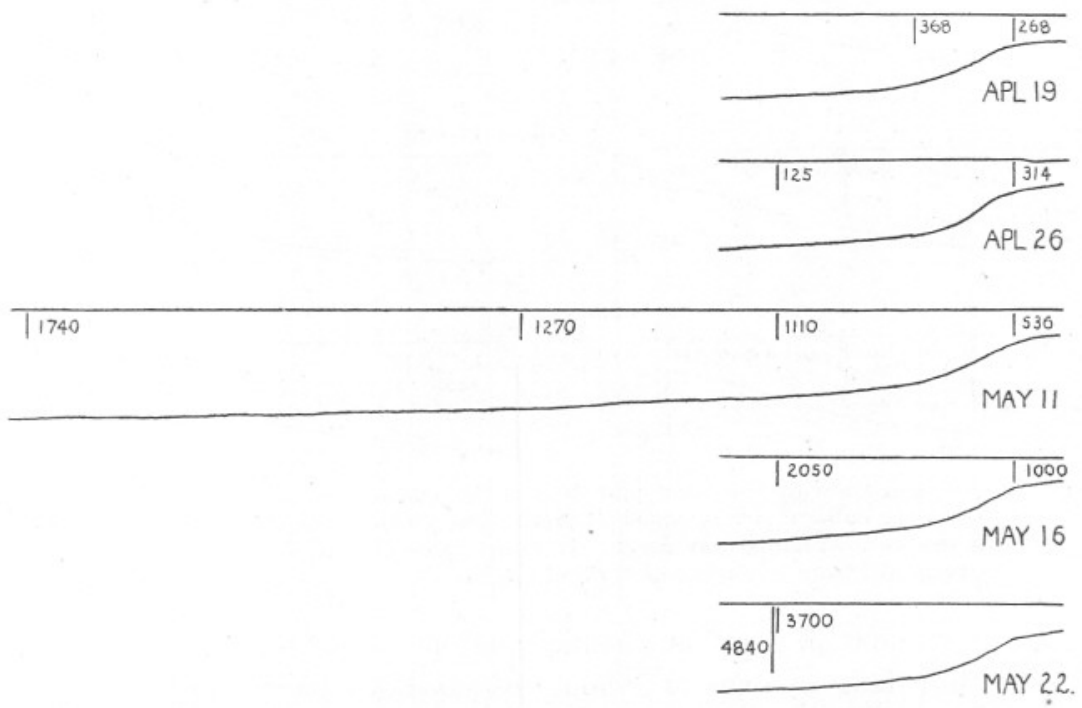

FIG. 2.- Sections showing the plant pigments in the catches, expressed as units of plant pigments per cubic metre of water filtered. The vertical lines indicate the depth to which the vertical hauls were made. In many cases the values shown are the mean value obtained from a number of vertical hauls.

NEW SERIES.-VOL. XIX. NO. 2. MAY, 1934. 
mass of water which has had a very different history may move in, unheralded by any big change in salinity.

\section{The Spring Diatom Outburst, 1933.}

The earliest observations at the beginning of February showed a very barren condition close inshore; on February 11th in Cawsand Bay only
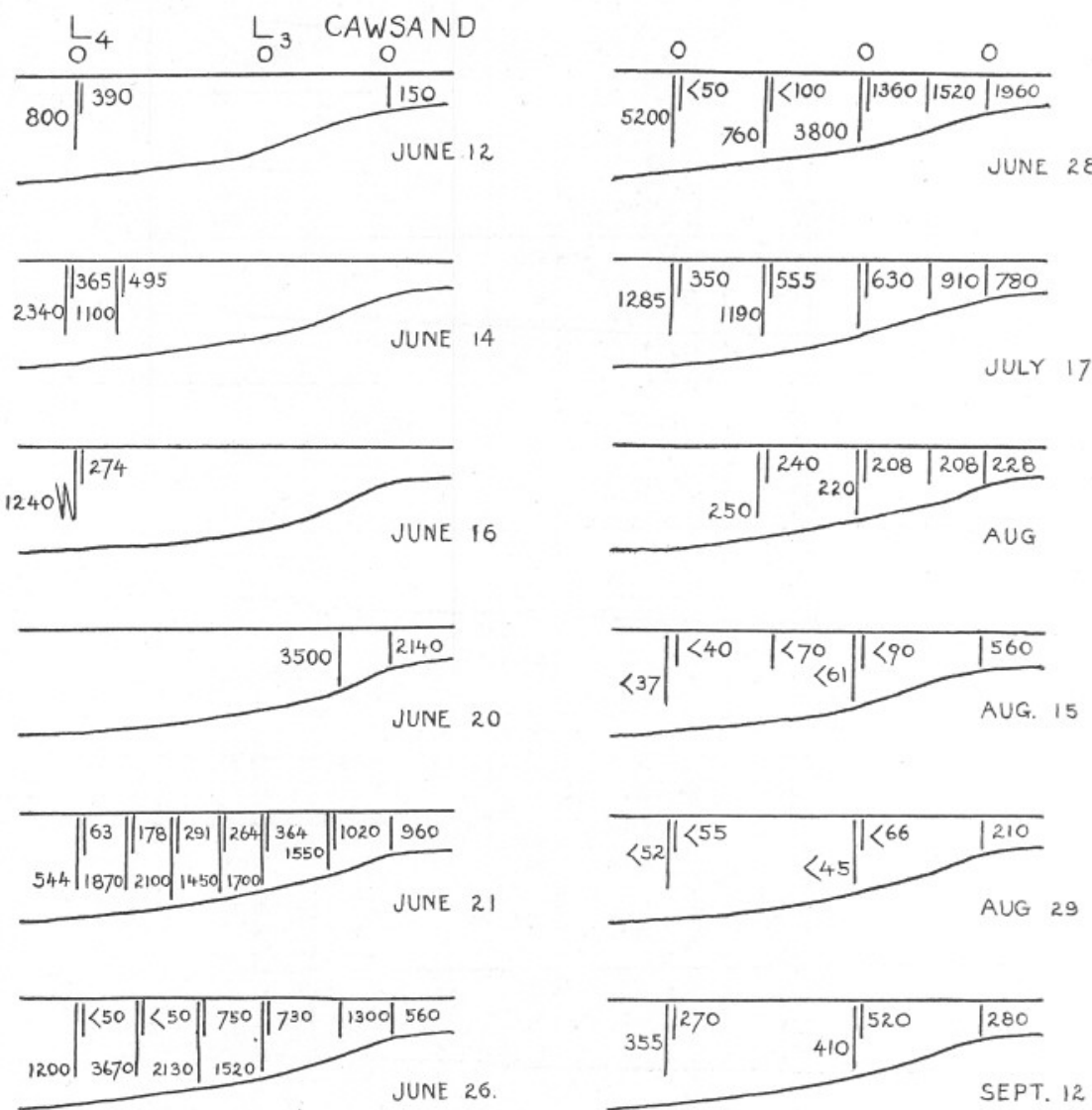

FIG. 3.-Sections showing the plant pigments in the catches, expressed as units of plant pigments per cubic metre of water filtered. The vertical lines indicate the depth to which the vertical hauls were made. In many cases the values shown are the mean value obtained from a number of vertical hauls.

about 15 'units of plant pigments' per $\mathrm{m}^{3}$ were found. After five days with a daily average of 5 hours of sunshine, on February 16th, a series of horizontal and oblique hauls were made farther to seaward, the results of which are expressed in Figure 2.

On March 8th, after 20 lengthening days with an average of 3.8 hours of 
sunshine daily, a series of vertical hauls showed a tenfold increase since February 16th.

The observations on March 13th after a further five days of sunny weather showed further increase, and a similar density of population
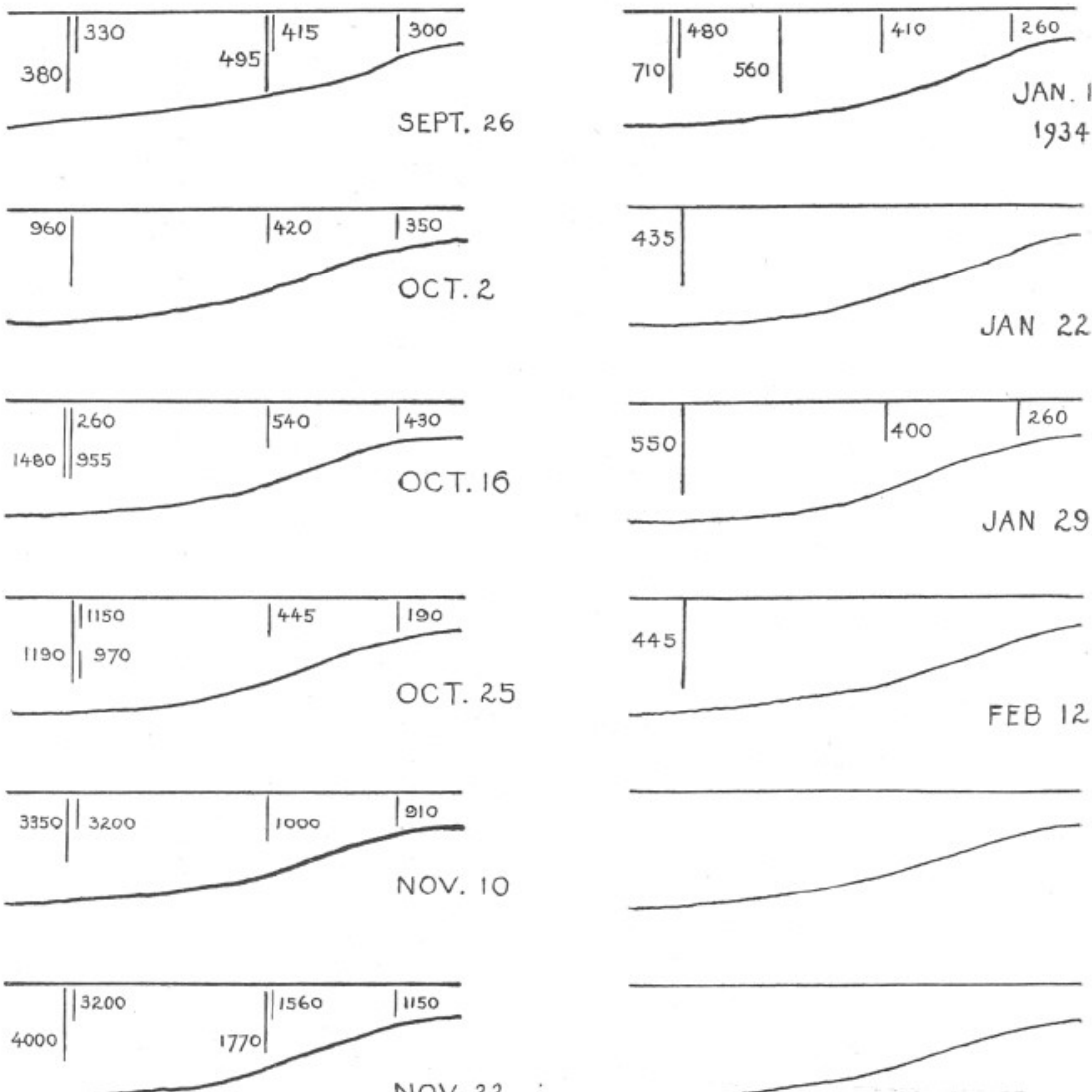

NOV. 22
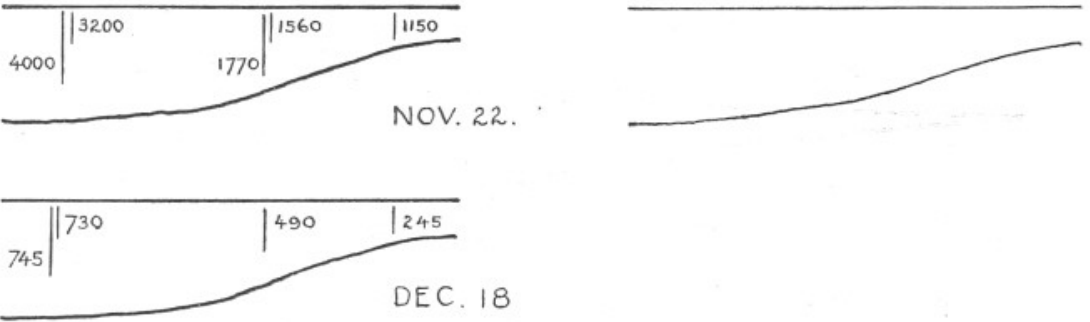

FIG. 4.- Sections showing the plant pigments in the catches, expressed as units of plant pigments per cubic metre of water filtered. The vertical lines indicate the depth to which the vertical hauls were made. In many cases the values shown are the mean value obtained from a number of vertical hauls.

extending 15 miles to seaward beyond the position $\mathrm{L}_{4}$. The flora was very mixed, many species of diatoms being present. Counts were made, but they only serve to give a general idea of the composition of the catch. 


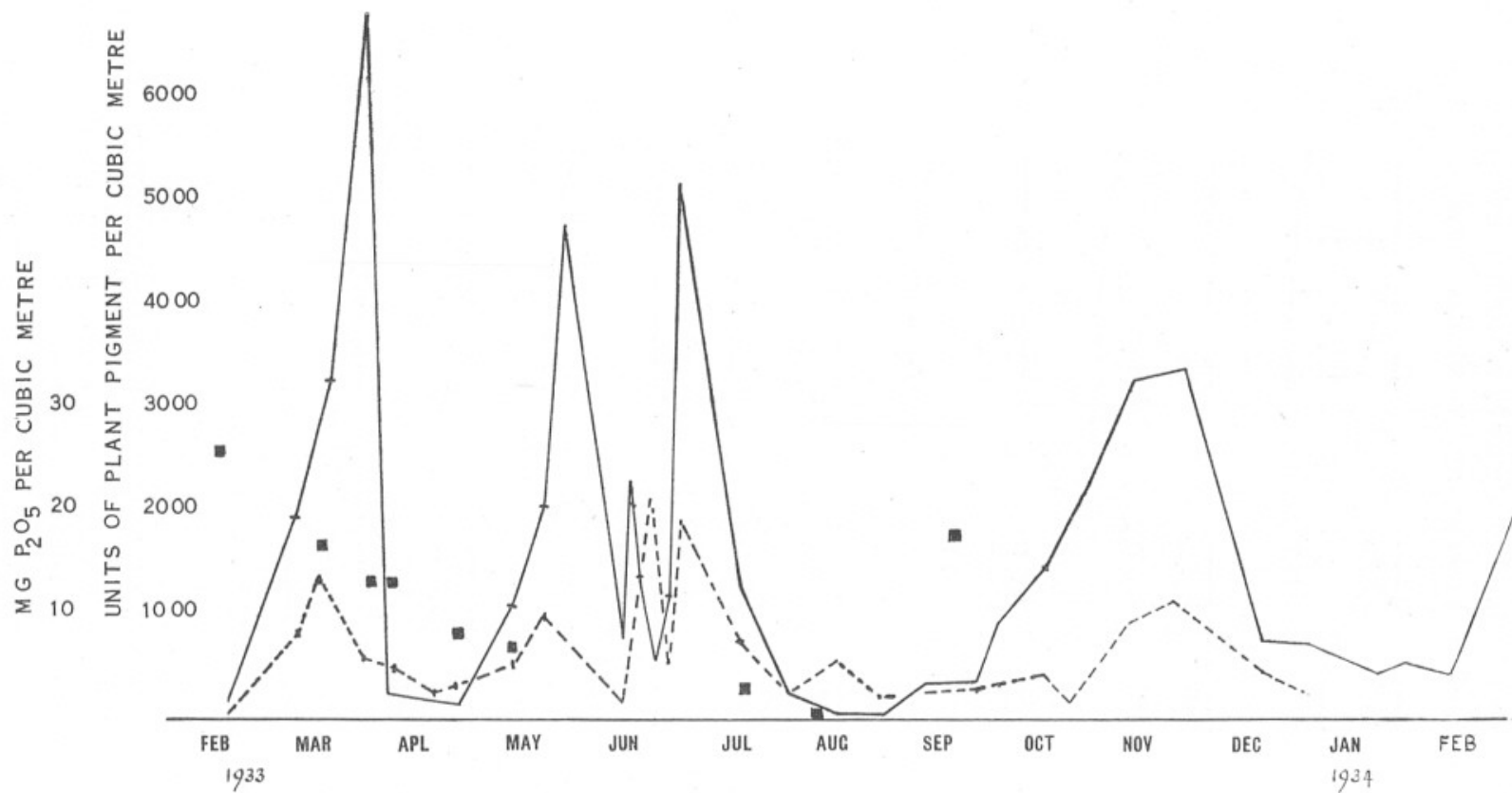

FIG. 5.-Diagram showing the mean content of plant pigments in the column of water at Station $\mathrm{L}_{4}$ (plain line) and at the inshore station (pecked line). The black squares show the phosphate content of the column of water between surface and bottom at Station $\mathrm{L}_{4}$. 
because too few cells were counted. In fact, it was later concluded that such counts were likely to be misleading unless the diatoms in many fields under the microscope were counted and numbered in all 500 or more. This was not done except on a few occasions where it was desired to link up the pigment content with the number of individual cells. The following table only provides a general indication of the composition of the catches.

\section{TABLE I.}

Number of Individual Cells per Litre, March 13th, 1933.

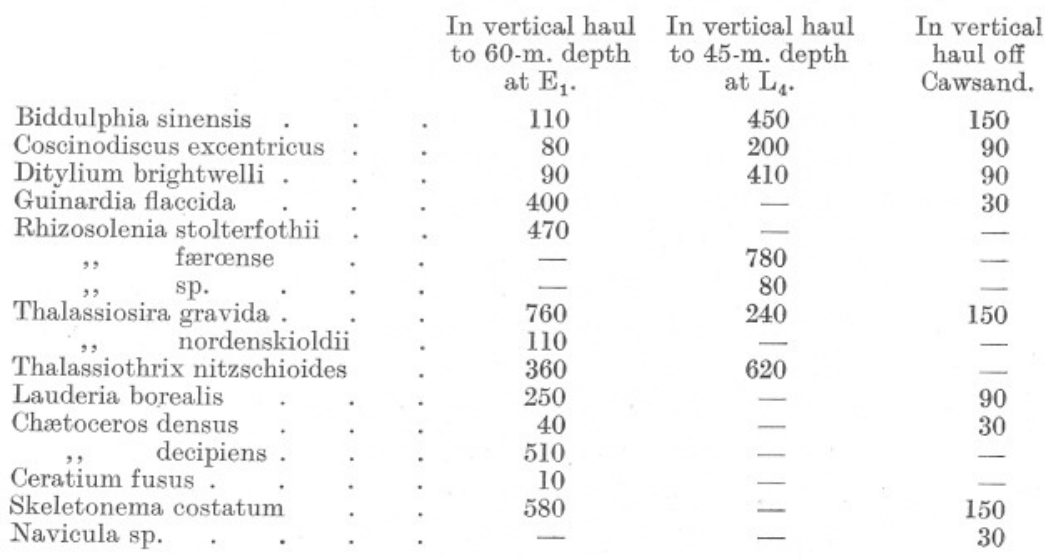

After a further period of 15 days, having a daily average of $6 \cdot 8$ hours' sunshine, a series of observations were made on March 28th, when the maximum spring population was found. The composition of the flora had remained much the same except that Guinardia was present in some quantity at $\mathrm{L}_{4}$.

Throughout this period of increasing diatom population between winter and spring, planktonic animals were not noticeably numerous, quite half the catch in the fine nets appeared to consist of diatoms.

Nevertheless, this maximum population only represents those diatoms which had not been eaten or died during the previous six weeks. Some 7000 units of plant pigment per cubic metre of water does not represent the six weeks' production of vegetable matter, for there is evidence that considerably more had been produced. I am indebted to Dr. L. H. N. Cooper for analyses showing the phosphate content of the water in the area. At $\mathrm{L}_{4}$ the dissolved phosphate in the column of water from surface to bottom had fallen from 26 to $13 \frac{1}{2} \mathrm{mg} . \mathrm{P}_{2} \mathrm{O}_{5}$ per m. ${ }^{3}$ during this period of six weeks (Feb. 16th-March 28th), indicating that $12 \frac{1}{2} \mathrm{mg} . \mathrm{P}_{2} \mathrm{O}_{5}$ had been utilised in the production of diatoms - on the assumption that the water-mass had not changed. Since the sea at the beginning of the period. 
contained an equal quantity of phosphate farther out to sea, and at the end of March rather more than at $\mathrm{L}_{4}$, and since the water in Plymouth Sound contains more phosphate than at $\mathrm{L}_{4}$, the likelihood is that any movement of water to the $\mathrm{L}_{4}$ position brought a little phosphate with it. Hence the value $12 \frac{1}{2} \mathrm{mg}$. utilised is if anything on the low side.

These values are expressed in the customary manner, no correction being made for salt error. If this be taken into account, the value $12 \frac{1}{2}$ becomes $15 \frac{1}{2} \mathrm{mg}$. $\mathrm{P}_{2} \mathrm{O}_{5}$ per $\mathrm{m}^{3}$.

I am indebted also to Dr. Cooper for analyses of the total phosphorus contained in a catch of diatoms. These consisted for the most part of Biddulphia sinensis and Thalassiosira sp. and were nearly free from zooplankton. A description of the method of analysis which was finally employed is published in this Journal, Vol. XIX, pp. 755-759. The pigment content of a part of the catch was estimated directly they were caught, and the remainder divided into three parts to allow analysis in triplicate.

The result showed that a quantity of diatoms containing 1000 units of plant pigment contained phosphorus amounting to $0.31 \mathrm{mg}$. when expressed as $\mathrm{P}_{2} \mathrm{O}_{5}$.

Several other catches, consisting mainly of diatoms, were analysed. They were not as free from animals and detritus as in this case, but after making allowance for this, they confirmed the value arrived at as representative for the mixed diatoms which flourish in winter. The assumption is made, pending further investigations, that the value is also more or less representative for summer diatoms.

From this it is deduced that at the time of the diatom outburst, when each cubic metre contained some 7000 units of plant pigment, the diatoms contained some $2 \mathrm{mg}$. $\mathrm{P}_{2} \mathrm{O}_{5}$. Since they had utilised over $15 \mathrm{mg}$. $\mathrm{P}_{2} \mathrm{O}_{5}$ during the previous six weeks, seven to eight times the quantity of diatoms found on March 28th had been produced. Seven-eights of this estimated six weeks' production had disappeared either by having been eaten, or much less likely by having died.

Neither this estimate, nor any one of those which follow, can by itself be considered as more than indicative. Each is subject to obvious reservations. But, taken as a whole, they present a consistent picture of a well, and often heavily, grazed pasturage of diatoms during the first half of the year.

The increase in population during the twenty-day period between March 8 th and 28 th at $\mathrm{L}_{4}$ contained some 5000 units of plant pigment per cubic metre, and hence phosphorus amounting to $1 \frac{1}{2} \mathrm{mg}$. $\mathrm{P}_{2} \mathrm{O}_{5}$. The phosphate in the water utilised during this period amounted to some 7 or $8 \mathrm{mg}$. $\mathrm{P}_{2} \mathrm{O}_{5}$ per cubic metre after making allowance for salt error. This quantity of phosphate would be contained in diatoms having 22,000 
to 26,000 units of plant pigments, or five times more diatoms than the observed increase in population. During this period of the spring outburst, conditions were clearly satisfactory for diatom growth, there was both sunshine and an ample supply of nutrient salts. It is improbable that diatoms died in any quantity; however, if we imagine that all the phytoplankton present on March 8th died naturally before the 28th, a similar calculation indicates that four to five times the nett increase had actually been produced.

It appears, therefore, that throughout this period of rapid increase the diatoms were being well grazed by the herbivorous animals.

The rate at which the diatoms reproduced is of interest. During the 20 days the mean population or "breeding stock" contained some 4200 units of pigment. The total calculated production lies between 22,000 and 26,000 units of pigment. This points to the breeding stock having divided about six times, or, on the average, once every $3 \frac{1}{2}$ days. If the diatoms were not being grazed the actual increase in abundance could be accounted for by less than two divisions during the 20 days.

\section{The First Outburst of Larve.}

As already mentioned the catches consisted of diatoms with only a moderate or small proportion of animal plankton. On April 4th, one week after the observations of maximum diatom population, the catches were equally large or larger, but consisted mostly of larvæ with only a small amount of phytoplankton-most in the inshore water. The catches also contained a great number of small fæcal pellets, most of which were tinted green with plant pigment.

It is concluded that the outburst of planktonic larvæ which occurred during this week had grazed down the pasturage of diatoms. There is no reason to suppose that the diatoms had ceased proliferating, because there was still plenty of phosphate in the water (Fig. 5) and there was an average of seven hours of sunshine daily during the week. There is no evidence that the water mass occupying the area on March 28th had moved away by April 4th to be replaced by water from another area in which there had been different conditions for growth. Neither salinity nor phosphate content had altered materially. The character of the phytoplankton had changed, at the Cawsand position and at $\mathrm{L}_{6}$ where the diatoms had remained most abundant some of the large Biddulphia sinensis and Guinardia remained, at $\mathrm{L}_{4}$ these seemed to have been eaten, the more spiny Chætoceros and Rhizosolenia remaining, and the peridinians Ceratium fusus and Peridinium depressum appeared in the catches.

Unfortunately, only one haul was made below 20 metres on April 4th, from surface to near the bottom at $\mathrm{E}_{1}$. The result showed water very 
barren of diatoms. This does not support the unlikely possibility that the diatoms had died in the surface layers and had sunk.

Throughout April and early May small diatom-feeding larvæ remained numerous and the phytoplankton sparse. At $\mathrm{L}_{4}$ on April 26th the catch consisted for the most part of larvæ and numerous fæcal pellets, with Chatoceros densus and Thalassiosira sp. dominant amongst the few diatoms; by May 11th Rhizosolenia alata had become dominant and the daily production of diatoms considerable.

Although the observations showed that the stock of diatoms at any time was small, the phosphate content of the water continued to fall. A decrease of about $8 \frac{1}{2} \mathrm{mg} . \mathrm{P}_{2} \mathrm{O}_{5}$ per m. ${ }^{3}$ between April 4th and May 11th at $\mathrm{L}_{4}$ indicates the production of diatoms containing some 27,000 units of pigment in each cubic metre of water, or an average of some 700 units daily. The observations, which are admittedly insufficient, indicate that less than this quantity was present in the water on the average and suggest that the diatoms present had divided as often as twice daily to produce 27,000 units of pigment in 5 weeks.

The rate of production suggested by this calculation appears at first sight excessive. However, Gran (1933) found that Chætoceros at $1 \frac{1}{2}$ metres below the surface at Woods Hole, one month after midsummer, made seven divisions in three days and other species five to six divisions. In other words, they produced three times their own weight of vegetation daily. During this period at $\mathrm{L}_{4}$, two months before the summer solstice, there was an average of $5 \cdot 8$ hours of sunshine daily. Certainly the water at $\mathrm{L}_{4}$ was poor in nutrient salts compared with that used in Gran's experiments. From this it seems that although the calculated rate of production at $\mathrm{L}_{4}$ may be excessive, it is not absurdly so.

To sum up, the evidence as a whole indicates that with lengthening days and increasing sunshine the stock of diatoms increased from February to March 28th, producing more daily than was eaten by the herbivores. Then a sudden outburst of larvæ rapidly ate down the stock of diatoms to a low level, and kept it eaten down closely for the following five weeks, during which time the small stock was producing vegetable food for the herbivores. Rough calculation, based on the assumption that water of different origin had not moved into the area, suggests that the stock was producing more than its own weight of vegetable food daily.

At Cawsand on May 11th the catch was composed as follows :-

Rhizosolenia alata .
,', styliformis
Ceratium fusus .
Guinardia flaccida .
Gyrosigma sp.

3440 individual cells per litre.

82

41

20

40

comparable in cell contents to some 3900 cells of $R$. alata per litre, and contained $0 \cdot 536$ units of plant pigment per litre. Hence 1 unit of plant pigment was contained in about 7300 cells of $R$. alata. 


\section{The Outbursts of Rhizosolenia alata IN MAY AND of R. stolterfothii IN JunE.}

During the five days between May 11th and 16th the diatom population at both $\mathrm{L}_{4}$ and the Cawsand station had doubled. At $\mathrm{L}_{4}$ the diatoms consisted almost entirely of $R$. alata, which allowed another assessment of the unit of pigment to be made in terms of this diatom. A similar value was obtained, one unit of pigment being contained in 6950 individual cells. The species was a small form. At the Cawsand station the same species was dominant with some Chotoceros densus and Skeletonema.

On May 22nd an extensive series of hauls were made at $\mathrm{L}_{4}$ and at positions 2 miles either side in a direction parallel to the coast, in order to investigate the uniformity of the population (p. 772). The diatoms again consisted almost entirely of $R$. alata which had attained a considerable density, over 30,000 cells per litre. The maximum occurred below the 20-metre level and doubtless exceeded 40,000 cells per litre in patches.

It is interesting to compare the density of this species in the Gulf of Maine, when a maximum of 50,000 cells per litre were found on August 4th, 1932, at 26 metres, less above and below, at one station- " a nearly maximal density" (Gran, 1933). The size of the cells may have been much larger, if they were one of the several other "forms" of this species.

By June 12th this population had been grazed down or had died down, much zooplankton and their fæcal pellets being present in the catch. The association of plants had changed to a very mixed plankton with Ceratium fusus, R. alata, and styliformis dominant. On both the 12 th and 16 th there was a greater density of population below the 20 -metre level. On June 16th a haul was made several times up and down between the 20- and 40-metre levels (Fig. 3) which substantiated this vertical distribution, $R$. stolterfothii and Guinardia flaccida being dominant in the catch. By this time the upper 20 metres had probably been depleted of nutrient salts.

On June 20th an outburst of these two species was found close inshore, the hauls containing very little zooplankton.

On June 28th considerable quantities of these diatoms, mostly $R$. stolterfothii were found at $\mathrm{L}_{4}$ below the 20 -metre level. The dominance of this species persisted throughout July.

From the middle of June throughout the summer copepods were numerous.

During this period of dominance of $R$. stolterfothii, sporadic outbursts are indicated in the shallow inshore waters-the marked outburst on June 20th occurring at a time when zooplankton was for some reason scarce - and sporadic outbursts farther to seaward in the deeper water. The sections (Fig. 3) suggest that in June the zooplankton may have 
occurred in swarms, accounting for the uneven distribution of diatoms. Herdman (1922) notes that in the Irish Sea during the diatom outburst there is greater uniformity in adjacent hauls than at other times when a zooplankton was present. There is evidence of a lack of nutrient salts in the upper layers beyond the coast about this time (Fig. 5).

It was noted that zooplankton was relatively sparse, both when $R$. alata was dense in May and $R$. stolterfothii dense later, suggesting that the summer outbursts occur only when and where the demand of the herbivores slackens, and, naturally, where there are enough nutrient salts. I did not realise this early in the summer, and no measurements of the zooplankton were made, so the suggestion can only be put forward as such. The evidence so far accumulated points to the important part played by the herbivorous zooplankton in regulating the vegetable population. If this is not the explanation of why some species of the mixed diatom population in March did not proliferate and use up the remaining nutrient salts, we have to fall back upon some idiosyncrasy of the diatoms themselves, or lack of some unknown constituent in the water which is but slowly reformed, as explanation. Of these we have no real evidence ; certainly cultures of oceanic diatoms tend to die out, but then such cultures are immensely dense compared with conditions in the sea. The suggested explanation can account for smaller outbursts occurring at intervals or sporadically during the early summer while there are still nutrient salts in the water. When it is borne in mind that diatoms can, and do, more than double their weight daily in the sea under optimal conditions, an explanation is necessary to account for some of the numerous species present not increasing in numbers sufficiently to use up the available nutrient salts before the end of the spring.

\section{The August Scarcity.}

By August 1st diatoms, of which $R$. stolterfothii remained dominant, had become scarce. On the 15 th and 29 th they must have been very scarce indeed. Many pigmented copepods were present, which rendered colour comparison of the extracted pigment uncertain, so that all one could do was to obtain a maximum value for the yellow-green plant pigments in the acetone extract. It is probable that these maximum values, small though they are, are themselves considerably greater than the actual. During this period lack of nutrient salts limited the production; on the 9th the surface water was found free from phosphate and at 49 metres only $2 \mathrm{mg}$. $\mathrm{P}_{2} \mathrm{O}_{5}$ per m. ${ }^{3}$. Since mid-July life had become dependent upon the phosphate and ammonium salts being excreted and reformed from dead organisms.

It is of interest to consider the rate at which nutrient salts are supplied 
to the water during the summer, although these observations only allow the roughest calculation to be made. If we assume that throughout August phytoplankton in the $\mathrm{L}_{4}$ water contained no more than 50 units of pigment per $\mathrm{m}^{3}$ and the organisms reproduced daily - the month's production contained 1500 units of colour or $0.47 \mathrm{mg} . \mathrm{P}_{2} \mathrm{O}_{5}$ per m. ${ }^{3}$. This suggests that until the end of August and the dying down of the summer zooplankton, only a very small quantity of phosphate was regenerated and used again, and that the phosphorus abstracted from the water in the form of phosphate by the phytoplankton earlier in the year was kept almost entirely locked away as phosphoproteins in the animals until the end of August in this relatively shallow area. However, farther to seaward we have evidence that regeneration of phosphate took place in considerable quantity before the end of July in several previous years (Atkins, 1930).

In the shallow inshore waters, which had probably some nutrient salts available, diatoms were present during August when the water offshore was barren.

\section{The Autumn and Winter Conditions.}

In September the copepods in the catches decreased and a mixed diatom plankton appeared, Rhizosolenia styliformis and Biddulphia sinensis being dominant. On the 19th, at both surface and bottom, the water contained $19 \mathrm{mg} . \mathrm{P}_{2} \mathrm{O}_{5}$ per cubic metre, indicating that death and decay of much of the summer plankton had taken place. There seems to be a possible lag in time between the proliferation of the diatoms and the appearance of a supply of phosphate. This was expected, because in previous years, when analyses of nitrate in the water were made, the regeneration of nitrate was found to have taken place a little later than that of phosphate. No measurements of the quantity of zooplankton in the water were made and no evidence obtained of the date at which great quantities apparently died, nor have we any knowledge of the length of time taken for phosphate to be regenerated from dead zooplankton, a question open to experimental attack. It is thought that rather wholesale death of herbivorous organisms and some of the carnivores dependent upon them for food was brought about at the end of August through starvation.

By the end of September zooplankton was sparse. During October and November there was much sunshine and few herbivorous animals in the catches; the diatoms increased, maximum catches being obtained on November 22nd when the same two diatom species were dominant as in September.

With regard to the autumn outburst Herdman remarks that this only takes place when the weather conditions are satisfactory. With respect to illumination, the autumn of 1933 had considerably more sunshine than 
normal in September and slightly more than normal in October and November.

The observations made during these two months show an even vertical distribution at $\mathrm{L}_{4}$, which does not suggest a loss due to diatoms dying and sinking to the bottom, which undoubtedly takes place at some times and in some areas. In fact, no evidence of this has emerged, although it may sometimes occur in this area.

During the winter months of December, January, and February, 1934, considerable quantities of diatoms were present. At no time was the water other than well-seeded with diatoms. The community was very mixed, Biddulphia, Coscinodiscus, and Thallassiosira species being dominant. In one respect these winter months were quite unusual, considerably less phosphate being found in the water than in previous years. In view of this unusual condition it is not possible to judge whether the rather considerable diatom population during the winter was a normal phenomenon.

\section{The Inshore Station.}

The quantity of phytoplankton at the inshore station off Cawsand remained low throughout the year (Fig. 5). Except during April and August there was consistently less than farther out to sea. During the winter months this may be due to the lesser transparency of the water ; but no reason is obvious for the small quantities found in summer, because in previous years the water here was found to be richer in nutrient salts than farther to seaward.

\section{DISCUSSION.}

The first half of the year 1933 was marked by much sunshine, an absence of strong winds, and a rather early spring maximum of diatoms. The seasonal change in dissolved phosphate in the water as it was utilised by the phytoplankton was in no way remarkable. A proliferation and spring maximum of diatoms, their very sudden decrease in numbers before all the dissolved phosphate is used up, and secondary maxima in the early summer are quite usual.

The data collected allow a picture to be drawn which accounts for the big changes which occur in the phytoplankton population during the year. The estimates arrived at, upon which this picture of the regime of the vegetation depends, are based to some extent on certain assumptions which are not rigidly true. However, even if some of the true average values are grossly different from those estimated, the same general picture is still presented, only modified in degree. Changes of several hundred per cent are being dealt with, so that errors amounting to 50 or even 100 
per cent due to sampling or renewal of the water from elsewhere do not necessarily destroy the general picture.

In the first place it is concluded that several times more vegetation is produced during the few weeks' proliferation than is found at the spring maximum. The decrease in phosphate content of the water during this period was in no way unusual. Atkins records the daily decrease in phosphate at $\mathrm{E}_{1}$ during spring diatom outbursts as varying between 0.40 and $1.06 \mathrm{mg} . \mathrm{P}_{2} \mathrm{O}_{5}$ per cubic metre for the whole column of water from surface to bottom. During the few weeks of the spring increase in Loch Strivan, between March 23rd and April 20th, 1926, Marshall and Orr record a fall from 44 to $30 \mathrm{mg}$. $\mathrm{P}_{2} \mathrm{O}_{5}$ per $\mathrm{m}^{3}$ in the column of water from surface to bottom, that is a fall of some $20 \mathrm{mg} \cdot \mathrm{P}_{2} \mathrm{O}_{5}$ per m. ${ }^{3}$ after allowing for salt error. The spring maximum of diatoms at $\mathrm{L}_{4}$ as found on March 28th may have been less than the average maximum attained, although there is no evidence to suggest this. If we imagine that the true average was even three times the quantity found, it then contained phosphorus amounting to about $6 \mathrm{mg}$. $\mathrm{P}_{2} \mathrm{O}_{5}$ per $\mathrm{m} \cdot{ }^{3}$, which is less than half the decrease in dissolved phosphate during the previous six weeks.

It is next concluded that this excess of production over increase in population was eaten and did not die. There was no evidence of dead diatoms in the catches, and an enormous death rate amongst actively dividing diatoms is against our present knowledge.

It is then concluded that at the end of March the population was rather suddenly eaten down to a low level. For this to happen would only require a moderate increase in the intensity of grazing by the herbivores, if their activities in eating the greater part of the production prior to the end of March is admitted. We have the general observation of a great increase in the quantity of zooplankton on April 4th, and the very noticeable presence in the catch of great quantities of fæcal pellets tinted green with diatom remains, which by itself is strong circumstantial evidence. If this is not the explanation of the decrease in diatom population, we have not only to fall back upon their death during a time when there was ample illumination and ample nutrient salts in the water, due to some peculiar idiosyncrasy of the plants themselves, but to neglect the evidence of fæcal pellets, of increased zooplankton, and lack of dead diatoms on April 4th.

During the early summer the greater part of the catches consisted of zooplankton, requiring a considerable daily ration of diatoms for their maintenance. If we concede that during March, when the relative proportion of herbivores was much less, a considerable part of the daily production of diatoms was eaten, it follows that during the early summer grazing was very intense. Fluctuations in the numbers of herbivores can readily account for the secondary diatom maxima during early summer. 
Such fluctuations amongst copepods, which perhaps make up the greater number of herbivores, are known to occur, cf. Calanus finmarchicus (Nicholls, 1933). This provides a simple explanation of a hitherto unexplained occurrence.

During the winter months at the beginning of the year, the amount of sunshine and transparency of the water without doubt keeps the daily production of diatoms from greatly exceeding the herbivores' requirements, in March the lengthening days and greater illumination allow an increase in vegetation. From then onwards the diatom population is regulated by the intensity of grazing, until it has used up the nutrient salts in the water. The utilisation of the nutrient salts and onset of barren conditions would presumably occur in the spring, if the herbivores did not keep the breeding stock of plants eaten down.

It is seen that the available plant food for marine animals varies greatly throughout the year. There is good reason to suppose that the periods of plenty and periods of famine do not occur at the same time in different years. The incidence of sunshine varies greatly, some weeks being bright and allowing considerable growth of the phytoplankton, other weeks dull and so limiting it, particularly between October and April. The density of herbivorous animals - mostly the smaller zooplanktondoubtless varies at any particular time from year to year, on account of there being sufficiency or insufficiency of plant food, of the balance between herbivores and carnivores, and of temperature affecting their breeding time. Shortage of vegetation occurred in April at $\mathrm{L}_{4}$ during sunny weather when there was plenty of nutrient salts in the water.

An intimate relation or balance exists between the ever-varying populations of carnivores, herbivores, and vegetable food, which in its turn is sometimes controlled and always affected by the available nutrient salts and illumination. If the proportion of carnivorous to herbivorous animals is displaced for a period by an " abnormally " large number of carnivores, then the diatoms are free to flourish and increase their population. If, on the other hand, the balance is displaced for a period by an " abnormally " small proportion of carnivores, then the herbivores freed from their enemies can flourish, keep the breeding stock of vegetation closely grazed, and by so doing limit their own increase. This would automatically delay the utilisation of nutrient salts.

The total productivity of the sea in most northern areas is limited by the nutrient salts available in the illuminated upper layers, for these are entirely or almost entirely utilised before the end of summer. However, in the Southern ocean only a part is utilised before the end of summer. This unexplained occurrence leaves a gap in our present knowledge of the productivity of the sea. In addition to slower rates of proliferation in colder waters, to the diatoms being subject to vertical movements which 
may carry them rather soon below the range of sufficient light, the herbivorous population grazing upon them will tend to delay the utilisation of the very rich supply of nutrient salts, as it does elsewhere.

\section{SUMMARY.}

Vertical hauls were made with a very fine silk net having a meter attached, which measured the volume of water filtered, at positions off Plymouth throughout the year 1933.

The quantity of phytoplankton was assessed from its content of yellowgreen colouring matter, and expressed in terms of "units of plant pigments " per cubic metre of water filtered.

The diatom population per cubic metre at Station $\mathrm{L}_{4}$ on March 28th was estimated to contain phosphorus amounting to $2 \mathrm{mg} . \mathrm{P}_{2} \mathrm{O}_{5}$, whereas dissolved phosphate amounting to some $15 \mathrm{mg}$. $\mathrm{P}_{2} \mathrm{O}_{5}$ had been used from each cubic metre of water by the diatoms during the previous six weeks.

It is concluded that the production of phytoplankton during this period greatly exceeded the quantity found at the height of the spring outburst, and that the excess had been eaten by the herbivorous zooplankton.

Between March 28th and April 4th the phytoplankton decreased to one thirty-fifth, coincident with a noticeable increase in zooplankton. Great numbers of fæcal pellets tinted green and largely composed of the remains of diatoms were found in the catch on April 4th.

It is concluded that the sudden decrease in vegetation after the spring maximum was due to increased intensity of grazing by the increased numbers of herbivorous zooplankton.

Evidence is presented that between April and the end of July the phytoplankton population was regulated by the intensity of grazing by the zooplankton. Two secondary diatom maxima occurred during this period. A rough calculation indicates that the phytoplankton was producing more than its own weight of vegetable matter daily during the first five weeks of this period, the zooplankton meanwhile eating this daily supply of vegetation.

During August the water was almost barren of vegetation, except at the inshore station, coincident with almost complete lack of dissolved phosphate in the water at a short distance offshore.

A well-marked autumn outburst of diatoms occurred in October and November, and during the winter months the phytoplankton was over eight times more than in August.

I take this opportunity of acknowledging the help and co-operation of Dr. L. H. N. Cooper who has carried out all the phosphate analyses and, after developing a suitable method, the analyses of organic 
phosphorus, of Dr. M. V. Lebour for identifying many diatoms, of my colleagues, particularly Mr. F. S. Russell, for much information and helpful suggestions, of the personnel of the S.S. Salpa and M.B. Gammarus for patiently hauling the net through several miles of sea.

\section{REFERENCES.}

Atkins, W. R. G. 1930. Seasonal Variations in the phosphate and silicate content of sea-water in relation to the phytoplankton crop. Part V. Journ. Mar. Biol. Assoc., N.S., Vol. XVI, pp. 821-852.

Gran, H. 1933. Studies on the Biology and Chemistry of the Gulf of Maine. Bull. Biol., Vol. LXIV, No. 2, p. 171.

Herdman, W. A. 1922. Investigation of Plankton in the Irish Sea. Journ. Linn. Soc. Botany, Vol. 66, pp. 141-170.

Marshall, S. M., and Orr, A. P. 1927. The relation of the Plankton to some Chemical and Physical factors in the Clyde Sea Area. Journ. Mar. Biol. Assoc., N.S., Vol. XIV, pp. 837-868.

Nicholls, A. G. 1933. On the Biology of Calanus finmarchicus. Journ. Mar. Biol. Assoc., N.S., Vol. XIX, pp. 83-110. 